\title{
PEMBELAJARAN BERBASIS MULTIKULTURAL DI LEMBAGA SEKOLAH
}

\author{
Endang Retnoningsih \\ 83640451 \\ Universitas Terbuka \\ endangretningsih72@gmail.com
}

\section{PENDAHULUAN}

Pendidikan multibudaya adalah kebijakan dalam praktik pendidikan dalam mengakui, menerima, menghargai, dan menghormati latar belakang bangsa Indonesia yang beranekaragam budayanya. Pendidikan multibudaya adalah suatu sikap yang memahami adanya perbedaan budaya bangsa Indonesia sebagai suatu keunikan, dengan tanpa adaya diskriminatif antar perbedaan-perbedaan tersebut.

Pendidikan Multibudaya merupakan strategi pendidikan yang memanfaatkan keberagaman latar belakang kebudayaan dari para peserta didik sebagai salah satu kekuatan untuk membentuk sikap multikultural. Strategi ini amat bermanfaat bagi pihak sekolah untuk menanamkan konsep kebudayaan, perbedaan budaya, dan demokrasi dalam arti yang luas. Dalam konteks yang luas, pendidikan Multibudaya mencoba membantu menyatukan bangsa secara demokratis, dengan menekankan pada perspektif pluralitas masyarakat di berbagai bangsa, etnik, kelompok budaya yang berbeda. Dengan demikian sekolah dikondisikan untuk mencerminkan praktik dari nilai-nilai demokrasi.

Kurikulum menampakkan aneka kelompok budaya yang berbeda dalam masyarakat, bahasa, dan dialek dimana para peserta didik lebih baik berbicara tentang rasa hormat diantara mereka dan menjunjung tinggi nilai-nilai kerja sama, daripada membicarakan persaingan dan prasangka diantara sejumlah peserta didik yang berbeda dalam hal ras, etnik, budaya, dan kelompok status sosialnya

Pembelajaran multibudaya adalah pembelajaran yang didasari atas filosofi kebebasan, keadilan, kesederajatan, dan keseimbangan setiap hak-hak manusia, sekalipun setiap orang memiliki latar belakang budaya yang berbeda. Hakekat pendidikan Multibudaya mempersiapkan seluruh peserta didik untuk bekerja secara aktif menuju kesamaan struktur dalam organisasi dan lembaga sekolah. 
Pembelajaran berbasis Multibudaya berusaha memberdayakan peserta didik untuk mengembangkan rasa hormat kepada orang yang berbeda budaya, memberi kesempatan untuk bekerja bersama dengan orang atau kelompok orang yang berbeda etnis atau rasnya secara langsung.

Pendidikan Multibudaya juga membantu peserta didik untuk mengakui pandanganpandangan budaya yang beragam, mengembangkan kebanggan terhadap warisan budaya mereka. Selain itu pendidikan multibudaya diselenggarakan dalam upaya mengembangkan kemampuan peserta didik dalam memandang kehidupan dari berbagai perspektif budaya yang berbeda satu dengan yang lainnya

\section{A. Pengertian Pembelajaran Berbasis Multikultural}

Multikulturalisme adalah sistem keyakinan dan perilaku yang mengakui dan menghormati kehadiran semua kelompok yang beragam dalam suatu organisasi atau masyarakat, mengakui sosial-budaya mereka yang berbeda, dan mendorong dan memungkinkan kontribusi melanjutkan mereka dalam konteks budaya inklusif yang memberdayakan semua dalam organisasi atau masyarakat.

Pembelajaran multikultural adalah kebijakan dalam praktik pendidikan dalam mengakui, menerima dan menegaskan perbedaan dan persamaan manusia yang dikaitkan dengan gender, ras, dan kelas (Sleeter and Grant, 1988). Pendidikan multikultural adalah suatu sikap dalam memandang keunikan manusia dengan tanpa membedakan ras, budaya, jenis kelamin, seks, kondisi jasmaniah atau status ekonomi seseorang (Skeel, 1995). Pendidikan multikultural (multicultural education) merupakan strategi pendidikan yang memanfaatkan keberagaman latar belakang kebudayaan dari para peserta didik sebagai salah satu kekuatan untuk membentuk sikap multikultural. Strategi ini sangat bermanfaat, sekurang-kurangnya bagi sekolah sebagai lembaga pendidikan dapat membentuk pemahaman bersama atas konsep kebudayaan, perbedaan budaya, keseimbangan, dan demokrasi dalam arti yang luas (Liliweri, 2005). Pendidikan multikultural didefinisikan sebagai sebuah kebijakan sosial yang didasarkan pada prinsip-prinsip pemeliharaan budaya dan saling memiliki rasa hormat antara seluruh kelompok budaya di dalam masyarakat. Pembelajaran multikultural pada dasarnya merupakan program pendidikan bangsa agar komunitas multikultural dapat berpartisipasi dalam mewujudkan kehidupan demokrasi yang ideal bagi bangsanya (Banks, 1993).

Dalam konteks yang luas, pendidikan multikultural mencoba membantu menyatukan bangsa secara demokratis, dengan menekankan pada perspektif pluralitas masyarakat di 
berbagai bangsa, etnik, kelompok budaya yang berbeda. Dengan demikian sekolah dikondisikan untuk mencerminkan praktik dari nilai-nilai demokrasi. Kurikulum menampakkan aneka kelompok budaya yang berbeda dalam masyarakat, bahasa, dan dialek, dimana para pelajar lebih baik berbicara tentang rasa hormat di antara mereka dan menunjung tinggi nilai-nilai kerjasama, dari pada membicarakan persaingan dan prasangka di antara sejumlah pelajar yang berbeda dalam hal ras, etnik, budaya dan kelompok status sosialnya.

Pembelajaran berbasis multikultural didasarkan pada gagasan filosofis tentang kebebasan, keadilan, kesederajatan dan perlindungan terhadap hak-hak manusia. Hakekat pendidikan multikultural mempersiapkan seluruh siswa untuk bekerja secara aktif menuju kesamaan struktur dalam organisasi dan lembaga sekolah. Pendidikan multikultural bukanlah kebijakan yang mengarah pada pelembagaan pendidikan dan pengajaran inklusif dan pengajaran oleh propaganda pluralisme lewat kurikulum yang berperan bagi kompetisi budaya individual.

Pembelajaran berbasis multikultural berusaha memberdayakan siswa untuk mengembangkan rasa hormat kepada orang yang berbeda budaya, memberi kesempatan untuk bekerja bersama dengan orang atau kelompok orang yang berbeda etnis atau rasnya secara langsung. Pendidikan multikultural juga membantu siswa untuk mengakui ketepatan dari pandangan-pandangan budaya yang beragam, membantu siswa dalam mengembangkan kebanggaan terhadap warisan budaya mereka, menyadarkan siswa bahwa konflik nilai sering menjadi penyebab konflik antar kelompok masyarakat (Savage \& Armstrong, 1996). Pendidikan multikultural diselenggarakan dalam upaya mengembangkan kemampuan siswa dalam memandang kehidupan dari berbagai perspektif budaya yang berbeda dengan budaya yang mereka miliki, dan bersikap positif terhadap perbedaan budaya, ras, dan etnis (Farris \& Cooper, 1994).

Tujuan pendidikan dengan berbasis multikultural dapat diidentifikasi:

1. Untuk memfungsikan peranan sekolah dalam memandang keberadaan siswa yang beraneka ragam;

2. Untuk membantu siswa dalam membangun perlakuan yang positif terhadap perbedaan kultural, ras, etnik, dan kelompok keagamaan;

3. Memberikan ketahanan siswa dengan cara mengajar mereka dalam mengambil keputusan dan keterampilan sosialnya;

4. Untuk membantu peserta didik dalam membangun ketergantungan lintas budaya dan memberi gambaran positif kepada mereka mengenai perbedaan kelompok (Banks, dalam Skeel, 1995). 
Di samping itu, pembelajaran berbasis multikultural dibangun atas dasar konsep pendidikan untuk kebebasan (Dickerson, 1993; Banks, 1994); yang bertujuan untuk:

1. Membantu siswa atau mahasiswa mengembangkan pengetahuan, sikap dan keterampilan untuk berpartisipasi di dalam demokrasi dan kebebasan masyarakat;

2. Memajukan kebebasan, kecakapan, keterampilan terhadap lintas batas-batas etnik dan budaya untuk berpartisipasi dalam beberapa kelompok dan budaya orang lain.

\section{B. Alasan Perlunya Pembelajaran Berbasis Multikultural}

Rasional tentang pentingnya pendidikan multikultural, karena strategi pendidikan ini dipandang memiliki keutamaan-keutamaan, terutama dalam:

1. Memberikan terobosan baru pembelajaran yang mampu meningkatkan empati dan mengurangi prasangka siswa atau mahasiswa sehingga tercipta manusia (warga negara) antar budaya yang mampu menyelesaikan konflik dengan tanpa kekerasan (nonviolent);

2. Menerapkan pendekatan dan strategi pembelajaran yang potensial dalam mengedepankan proses interaksi sosial dan memiliki kandungan afeksi yang kuat;

3. Model pembelajaran multikultural membantu guru dalam mengelola proses pembelajaran menjadi lebih efisien dan efektif, terutama memberikan kemampuan peserta didik dalam membangun kolaboratif dan memiliki komitmen nilai yang tinggi dalam kehidupan masyarakat yang serba majemuk;

4. Memberikan kontribusi bagi bangsa Indonesia dalam penyelesaian dan mengelola konflik yang bernuansa SARA yang timbul di masyarakat dengan cara meningkatkan empati dan mengurangi prasangka.

Kondisi keberagaman masyarakat dan budaya, secara positif menggambarkan kekayaan potensi sebuah masyarakat yang bertipe pluralis, namun secara negatif orang merasa tidak nyaman karena tidak saling mengenal budaya orang lain. Setiap etnik atau ras cenderung mempunyai semangat dan ideologi yang etnosentris, yang menyatakan bahwa kelompoknya lebih superior daripada kelompok etnik atau ras lain (Jones, dalam Liliweri, 2003). Terjadinya tidak saling mengenal identitas budaya orang lain, bisa mendorong meningkatnya prasangka terhadap orang lain, berupa sikap antipati yang didasarkan pada kesalahan generalisasi yang diekspresikan sebagai perasaan. Prasangka juga diarahkan kepada sebuah kelompok secara keseluruhan, atau kepada seseorang hanya karena itu adalah anggota kelompok tertentu. Secara demikian, prasangka memiliki potensi dalam mengkambinghitamkan orang lain melalui stereotipe, diskriminasi dan penciptaan jarak sosial (Bennet dan Janet, 1996). 
Melalui pembelajaran multikultural, subyek belajar dapat mencapai kesuksesan dalam mengurangi prasangka dan diskriminasi (Banks, 1996). Dengan kata lain, variabel sekolah terbentuk dimana besar kelompok rasial dan etnis yang memiliki pengalaman dan hak yang sama dalam proses pendidikan. Pelajar mampu mengembangkan keterampilannya dalam memutuskan sesuatu secara bijak. Mereka lebih menjadi suatu subyek dari pada menjadi obyek dalam suatu kurikulum. Mereka menjadi individu yang mampu mengatur dirinya sendiri dan merefleksi kehidupan untuk bertindak secara aktif. Mereka membuat keputusan dan melakukan sesuatu yang berhubungan dengan konsep, pokok-pokok masalah yang mereka pelajari. Mereka mengembangkan visi sosial yang lebih baik dan memperoleh ilmu pengetahuan dan keterampilan serta mengkonstruksinya dengan sistematis dan empatis. Seharusnya guru mengetahui bagaimana berperilaku terhadap para pelajar yang bermacammacam kulturnya di dalam kelas. Mereka mengetahui perbedaan-perbedaan nilai-nilai dan kultur dan bentuk-bentuk perilaku yang beraneka ragam.

\section{Dimensi dan Pendekatan Pembelajaran Berbasis Multikultural}

James A. Banks (1993, 1994-a), mengidentifikasi ada lima dimensi pendidikan multikultural yang diperkirakan dapat membantu guru dalam mengimplementasikan beberapa program yang mampu merespon terhadap perbedaan pelajar (siswa), yaitu:

1. Dimensi integrasi isi/materi (content integration). Dimensi ini digunakan oleh guru untuk memberikan keterangan dengan 'poin kunci' pembelajaran dengan merefleksi materi yang berbeda-beda. Secara khusus, para guru menggabungkan kandungan materi pembelajaran ke dalam kurikulum dengan beberapa cara pandang yang beragam. Salah satu pendekatan umum adalah mengakui kontribusinya, yaitu guru-guru bekerja ke dalam kurikulum mereka dengan membatasi fakta tentang semangat kepahlawanan dari berbagai kelompok. Di samping itu, rancangan pembelajaran dan unit pembelajarannya tidak dirubah. Dengan beberapa pendekatan, guru menambah beberapa unit atau topik secara khusus yang berkaitan dengan materi multikultural.

2. Dimensi konstruksi pengetahuan (knowledge construction). Suatu dimensi dimana para guru membantu siswa untuk memahami beberapa perspektif dan merumuskan kesimpulan yang dipengaruhi oleh disiplin pengetahuan yang mereka miliki. Dimensi ini juga berhubungan dengan pemahaman para pelajar terhadap perubahan pengetahuan yang ada pada diri mereka sendiri;

3. Dimensi pengurangan prasangka (prejudice ruduction). Guru melakukan banyak usaha untuk membantu siswa dalam mengembangkan perilaku positif tentang perbedaan kelompok. Sebagai contoh, ketika anak-anak masuk sekolah dengan perilaku negatif dan 
memiliki kesalahpahaman terhadap ras atau etnik yang berbeda dan kelompok etnik lainnya, pendidikan dapat membantu siswa mengembangkan perilaku intergroup yang lebih positif, penyediaan kondisi yang mapan dan pasti. Dua kondisi yang dimaksud adalah bahan pembelajaran yang memiliki citra yang positif tentang perbedaan kelompok dan menggunakan bahan pembelajaran tersebut secara konsisten dan terus-menerus. Penelitian menunjukkan bahwa para pelajar yang datang ke sekolah dengan banyak stereotipe, cenderung berperilaku negatif dan banyak melakukan kesalahpahaman terhadap kelompok etnik dan ras dari luar kelompoknya. Penelitian juga menunjukkan bahwa penggunaan teksbook multikultural atau bahan pengajaran lain dan strategi pembelajaran yang kooperatif dapat membantu para pelajar untuk mengembangkan perilaku dan persepsi terhadap ras yang lebih positif. Jenis strategi dan bahan dapat menghasilkan pilihan para pelajar untuk lebih bersahabat dengan ras luar, etnik dan kelompok budaya lain.

4. Dimensi pendidikan yang sama/adil (equitable pedagogy). Dimensi ini memperhatikan cara-cara dalam mengubah fasilitas pembelajaran sehingga mempermudah pencapaian hasil belajar pada sejumlah siswa dari berbagai kelompok. Strategi dan aktivitas belajar yang dapat digunakan sebagai upaya memperlakukan pendidikan secara adil, antara lain dengan bentuk kerjasama (cooperative learning), dan bukan dengan cara-cara yang kompetitif (competition learning). Dimensi ini juga menyangkut pendidikan yang dirancang untuk membentuk lingkungan sekolah, menjadi banyak jenis kelompok, termasuk kelompok etnik, wanita, dan para pelajar dengan kebutuhan khusus yang akan memberikan pengalaman pendidikan persamaan hak dan persamaan memperoleh kesempatan belajar.

5. Dimensi pemberdayaan budaya sekolah dan struktur sosial (empowering school culture and social structure). Dimensi ini penting dalam memperdayakan budaya siswa yang dibawa ke sekolah yang berasal dari kelompok yang berbeda. Di samping itu, dapat digunakan untuk menyusun struktur sosial (sekolah) yang memanfaatkan potensi budaya siswa yang beranekaragam sebagai karakteristik struktur sekolah setempat, misalnya berkaitan dengan praktik kelompok, iklim sosial, latihan-latihan, partisipasi ekstra kurikuler dan penghargaan staf dalam merespon berbagai perbedaan yang ada di sekolah.

Pendekatan yang bisa dipakai dalam proses pembelajaran di kelas multikultural adalah pendekatan kajian kelompok tunggal (Single Group Studies) dan pendekatan perspektif ganda (Multiple Perspektives Approach). Pendidikan multikultural di Indonesia pada umumnya memakai pendekatan kajian kelompok tunggal. Pendekatan ini dirancang 
untuk membantu siswa dalam mempelajari pandangan-pandangan kelompok tertentu secara lebih mendalam. Oleh karena itu, harus tersedia data-data tentang sejarah kelompok itu, kebiasaan, pakaian, rumah, makanan, agama yang dianut, dan tradisi lainnya. Data tentang kontribusi kelompok itu terhadap perkembangan musik, sastra, ilmu pengetahuan, politik dan lain-lain harus dihadapkan pada siswa. Pendekatan ini terfokus pada isu-isu yang sarat dengan nilai-nilai kelompok yang sedang dikaji.

Sedangkan pendekatan perspektif ganda (Multiple Perspectives Approach) adalah pendekatan yang terfokus pada isu tunggal yang dibahas dari berbagai perspektif kelompokkelompok yang berbeda. Pada umumnya, guru-guru memiliki berbagai perspektif dalam pembelajarannya. Dalam kaitan ini, Bannet dan Spalding (1992) menyarankan agar pembelajaran menggunakan pendekatan perspektif ganda, dengan alasan pendekatan itu nampak lebih efektif.

Pendekatan perspektif ganda membantu siswa untuk menyadari bahwa suatu peristiwa umum sering diinterpretasikan secara berbeda oleh orang lain, dimana interpretasinya sering didasarkan atas nilai-nilai kelompok yang mereka ikuti. Solusi yang dianggap baik oleh suatu kelompok (karena solusi itu sesuai dengan nilai-nilainya), sering tidak dianggap baik oleh kelompok lainnya karena tidak cocok dengan nilai yang diikutinya (Savage \& Armstrong, 1996).

Keunggulan pendekatan perspektif ganda ini terletak pada proses berpikir kritis terhadap isu yang sedang dibahas sehingga mendorong siswa untuk menghilangkan prasangka buruk. Interaksi dengan pandangan kelompok yang berbeda-bebada memungkinkan siswa untuk berempati. Hasil penelitian (Byrnes, 1988) membuktikan bahwa siswa yang rendah prasangkanya menunjukkan sikap yang lebih sensitif dan terbuka terhadap pandangan orang lain. Mereka juga mampu berpikir kritis, karena mereka lebih bersikap terbuka, fleksibel, dan menaruh hormat pada pendapat yang berbeda (Walsh, 1988).

Bahan pelajaran dan aktivitas belajar yang kuat aspek afektifnya tentang kehidupan bersama dalam perbedaan kultur terbukti efektif untuk mengembangkan perspektif yang fleksibel (Byrnes, 1988). Siswa yang memiliki rasa empati yang besar memungkinkan dia untuk menaruh rasa hormat terhadap perbedaan cara pandang. Tentu saja hal itu akan mampu mengurangi prasangka buruk terhadap kelompok lain. Membaca buku sastra multietnik dapat mengurangi stereotipe negatif tentang budaya orang lain (Walker-Dalhouse, 1992). Pendekatan perspektif ganda mengandung dua sasaran yaitu meningkatkan empati dan menurunkan prasangka. Empati terhadap kultur yang berbeda merupakan prasyarat bagi upaya menurunkan prasangka. 


\section{Langkah Mengembangkan Pembelajaran Berbasis Multikultural}

Ada beberapa hal yang perlu dijadikan perhatian dalam mengembangkan pembelajaran berbasis multikultural, diantaranya:

\section{Melakukan Analisis Faktor Potensial Bernuansa Multikultural}

Analisis faktor yang dipandang penting dijadikan pertimbangan dalam mengembangkan model pembelajaran berbasis multikultural, yang meliputi: (a) tuntutan kompetensi mata pelajaran yang harus dibekalkan kepada peserta didik berupa pengetahuan (knowledge), keterampilan (skills), dan etika atau karakter (ethic atau disposition); (b) tuntutan belajar dan pembelajaran, terutama terfokus membuat orang untuk belajar dan menjadikan kegiatan belajar adalah proses kehidupan; (c) kompetensi guru dalam menerapkan pendekatan multikultural. Guru sebaiknya menggunakan metode mengajar yang efektif, dengan memperhatikan referensi latar budaya siswanya. Guru harus bertanya dulu pada diri sendiri, apakah ia sudah menampilkan perilaku dan sikap yang mencerminkan jiwa multikultural; (d) analisis terhadap latar kondisi siswa. Secara alamiah siswa sudah menggambarkan masyarakat belajar yang multikultural. Latar belakang kultur siswa akan mempengaruhi gaya belajarnya. Agama, suku, ras/etnis dan golongan serta latar ekonomi orang tua, bisa menjadi stereotipe siswa ketika merespon stimulus di kelasnya, baik berupa pesan pembelajaran maupun pesan lain yang disampaikan oleh teman di kelasnya. Siswa bisa dipastikan memiliki pilihan menarik terhadap potensi budaya yang ada di daerah masing-masing: (e) karakteristik materi pembelajaran yang bernuansa multikultural. Analisis materi potensial yang relevan dengan pembelajaran berbasis multikultural, antara lain meliputi: (1) menghormati perbedaan antar teman (gaya pakaian, mata pencaharian, suku, agama, etnis dan budaya); (2) menampilkan perilaku yang didasari oleh keyakinan ajaran agama masing-masing; (3) kesadaran bermasyarakat, berbangsa dan bernegara; (4) membangun kehidupan atas dasar kerjasama umat beragama untuk mewujudkan persatuan dan kesatuan; (5) mengembangkan sikap kekeluargaan antar suku bangsa dan antra bangsa-bangsa; (6) tanggung jawab daerah (lokal) dan nasional; (7) menjaga kehormatan diri dan bangsa; (8) mengembangkan sikap disiplin diri, sosial dan nasional; (9) mengembangkan kesadaran budaya daerah dan nasional; (10) mengembangkan perilaku adil dalam kehidupan; (11) membangun kerukunan hidup; (12) menyelenggarakan 'proyek budaya' dengan cara pemahaman dan sosialisasi terhadap simbol-simbol identitas nasional, seperti bahasa Indonesia, lagu Indonesia Raya, bendera Merah Putih, Lambang negara Garuda Pancasila, bahkan budaya nasional yang menggambarkan puncak-puncak budaya di daerah; dan sebagainya.

2. Menetapkan Strategi Pembelajaran Berkadar Multikultural 
Pilihan strategi yang digunakan dalam mengembangkan pembelajaran berbasis multikultural, antara lain: strategi kegiatan belajar bersama-sama (Cooperative Learning), yang dipadukan dengan strategi pencapaian konsep (Concept Attainment) dan strategi analisis nilai (Value Analysis), strategi analisis sosial (Social Investigation). Beberapa pilihan strategi ini dilaksanakan secara simultan, dan harus tergambar dalam langkah-langkah model pembelajaran berbasis multikultural. Namun demikian, masing-masing strategi pembelajaran secara fungsional memiliki tekanan yang berbeda. Strategi Pencapaian Konsep, digunakan untuk memfasilitasi siswa dalam melakukan kegiatan eksplorasi budaya lokal untuk menemukan konsep budaya apa yang dianggap menarik bagi dirinya dari budaya daerah masing-masing, dan selanjutnya menggali nilai-nilai yang terkandung dalam budaya daerah asal tersebut.

Strategi cooperative learning, digunakan untuk menandai adanya perkembangan kemampuan siswa dalam belajar bersama-sama mensosialisasikan konsep dan nilai budaya lokal dari daerahnya dalam komunitas belajar bersama teman. Dalam tataran belajar dengan pendekatan multikultural, penggunaan strategi cooperative learning, diharapkan mampu meningkatkan kadar partisipasi siswa dalam melakukan rekomendasi nilai-nilai lokal serta membangun cara pandang kebangsaan. Dari kemampuan ini, siswa memiliki keterampilan mengembangkan kecakapan hidup dalam menghormati budaya lain, toleransi terhadap perbedaan, akomodatif, terbuka dan jujur dalam berinteraksi dengan teman (orang lain) yang berbeda suku, agama etnis dan budayanya, memiliki empati yang tinggi terhadap perbedaan budaya lain, dan mampu mengelola konflik dengan tanpa kekerasan (conflict non violent). Selain itu, penggunaan strategi cooperative learning dalam pembelajaran dapat meningkatkan kualitas dan efektivitas proses belajar siswa, suasana belajar yang kondusif, membangun interaksi aktif antara siswa dengan guru, siswa dengan siswa dalam pembelajaran. Sedangkan strategi analisis nilai, difokuskan untuk melatih kemampuan siswa berpikir secara induktif, dari setting ekspresi dan komitmen nilai-nilai budaya lokal (cara pandang lokal) menuju kerangka dan bangunan tata pikir atau cara pandang yang lebih luas dalam lingkup nasional (cara pandang kebangsaan).

Bertolak dari keempat strategi pembelajaran di atas, pola pembelajaran berbasis multikultural dilakukan untuk meningkatkan kesadaran diri siswa terhadap nilai-nilai keberbedaan dan keberagaman yang melekat pada kehidupan siswa lokal sebagai faktor yang sangat potensial dalam membangun cara pandang kebangsaan. Dengan kesadaran diri siswa terhadap nilainilai lokal, siswa di samping memiliki ketegaran dan ketangguhan secara pribadi, juga mampu melakukan pilihan-pilihan rasional (rational choice) ketika berhadapan dengan isu- 
isu lokal, nasional dan global. Siswa mampu menatap perspektif global sebagai suatu realitas yang tidak selalu dimaknai secara emosional, akan tetapi juga rasional serta tetap sadar akan jati diri bangsa dan negaranya. Kemampuan akademik tersebut, salah satu indikasinya ditampakkan oleh siswa dalam perolehan hasil pembelajaran yang dialami.

Kriteria yang dapat digunakan untuk mengetahui keberhasilan kegiatan belajar siswa adalah laporan kerja (makalah), unjuk kerja dan partisipasi yang ditampilkan oleh siswa dalam pembelajaran dengan cara diskusi dan curah pendapat, yang meliputi rasional berpendapat, toleransi dan empati terhadap menatap nilai-nilai budaya daerah asal teman, serta perkembangan prestasi belajar siswa setelah mengikuti tes di akhir pembelajaran. Selain itu, kriteria lain yang dapat digunakan adalah unjuk kerja yang ditampilkan oleh guru di dalam melaksanakan pendekatan multikultural dalam pembelajarannya.

Guru yang bersangkutan selalu terlibat dalam setiap fase kegiatan pembelajaran, baik dalam kegiatan diskusi dan refleksi hasil temuan awal, penyusunan rencana tindakan, pelaksanaan tindakan, pengamatan dalam pelaksanaan tindakan, diskusi dan refleksi hasil pelaksanaan tindakan, dan penentuan/penyusunan rencana tindakan selanjutnya dalam pencapain tujuan pembelajaran.

\section{Ada 4 Pendekatan untuk Reformasi Kurikulum Multikultural yakni:}

\section{Pendekatan Kontribusi}

Pendekatan ini mencerminkan sedikitnya jumlah keterlibatan dalam pendekatan pendidikan multikultural. Hal ini dimasukkan dengan memilih buku-buku dan kegiatan yang merayakan hari libur, pahlawan, dan acara khusus dari berbagai budaya. Sebagai contoh, menghabiskan waktu membaca tentang Dr Martin Luther King pada bulan Januari adalah praktek umum yang termasuk dalam kategori ini. Dalam pendekatan ini, buku-buku budaya yang beragam dan isu-isu yang tidak ditentukan sebagai bagian dari kurikulum (Bank, 1999).

\section{The Additive Approach (Pendekatan Aditif)}

Dalam konten ini pendekatan, konsep, tema, dan perspektif ditambahkan ke kurikulum tanpa mengubah struktur dasar. Ini melibatkan menggabungkan literatur oleh dan tentang orang-orang dari beragam budaya ke dalam kurikulum utama tanpa mengubah kurikulum. Sebagai contoh, memeriksa perspektif asli Amerika tentang Thanksgiving akan menambahkan keragaman budaya dengan pandangan tradisional Thanksgiving. Namun, pendekatan ini tidak selalu mentransformasi pemikiran (Bank, 1999).

\section{The Transformation Approach (Pendekatan Transformasi)}


Pendekatan ini benar-benar mengubah struktur kurikulum dan mendorong siswa untuk melihat konsep, isu, tema, dan masalah dari perspektif etnik dan beberapa sudut pandang. Sebagai contoh, sebuah unit pada Thanksgiving akan menjadi seluruh unit mengeksplorasi konflik budaya. Ini jenis instruksi melibatkan pemikiran kritis dan melibatkan pertimbangan keberagaman sebagai premis dasar (Bank, 1999).

\section{The Social Action Approach (Pendekatan Sosial Aksi)}

Pendekatan ini menggabungkan pendekatan transformasi dengan kegiatan untuk berjuang untuk perubahan sosial. Siswa tidak hanya diperintahkan untuk memahami dan pertanyaan isu-isu sosial, tapi juga melakukan sesuatu yang penting tentang hal itu. Sebagai contoh, setelah berpartisipasi dalam sebuah unit tentang imigran baru ke Amerika Utara, siswa dapat menulis surat kepada senator, Kongres, dan editor surat kabar untuk mengekspresikan pendapat mereka tentang kebijakan baru (Bank, 1999).

\section{E. Solusi Guru Agar Mampu Menerapkan Pendidikan Multikultural}

Di Indonesia sebagian besar belum menerapkan pendidikan multikultural sebagaimana mestinya, oleh karena itu guru perlu memahami langkah-langkah penting dalam penerapan pendidikan multikultural. Sebelum melangkah atau menerapkan pembelajaran multikultural hendaknya guru memahami apa tujuan pendidikan multikultural. Tujuan pendidikan multikultural dapat dibedakan menjadi 3 (tiga) macam tujuan, yaitu: tujuan yang berkaitan dengan sikap, pengetahuan, dan pembelajaran (Lawrence J. Saha, 1997: 349). Tujuan pendidikan multikultural yang berkaitan dengan aspek pengetahuan (cognitive goals) adalah untuk memperoleh pengetahuan tentang bahasa dan budaya orang lain, dan kemampuan untuk menganalisis dan menerjemahkan perilaku kultural, dan pengetahuan tentang kesadaran perspektif kultural. Sedangkan tujuan pendidikan multikultural yang berkaitan dengan pembelajaran (instructional goals) adalah untuk memperbaiki distorsi, stereotipe, dan kesalahpahaman tentang kelompok etnik dalam buku teks dan media pembelajaran; memberikan berbagai strategi untuk mengarahkan perbedaan di depan orang, memberikan alat-alat konseptual untuk komunikasi antar budaya; mengembangkan keterampilan interpersonal; memberikan teknik-teknik evaluasi; membantu klarifikasi nilai; dan menjelaskan dinamika kultural.

\section{F. Strategi dan Manajemen Pendidikan Multikultural}

Dari aspek metodik, strategi dan manajemen pembelajaran merupakan aspek penting dalam pendidikan multikultural. Harry K. Wong, penulis buku How to be an Active Teacher the First Days of School, sebagaimana dikutip Linda Starr (2004: 2) mendefinisikan 
manajemen pembelajaran sebagai "praktik dan prosedur yang memungkinkan guru mengajar dan siswa belajar." Terkait dengan praktik dan prosedur ini, Ricardo L. Garcia (1982: 146) menyebutkan 3 (tiga) faktor dalam manajemen pembelajaran, yaitu:

1. Lingkungan fisik (physical environment)

Untuk menciptakan lingkungan fisik yang aman dan nyaman, guru dapat mempertimbangkan aspek pencahayaan, warna, pengaturan meja dan kursi, tanaman, dan musik. Guru yang memiliki pemahaman terhadap latar belakang budaya siswanya, akan menciptakan lingkungan fisik yang kondusif untuk belajar.

2. Lingkungan sosial (human environment)

Lingkungan sosial yang aman dan nyaman dapat diciptakan oleh guru melalui bahasa yang dipilih, hubungan simpatik antar siswa, dan perlakuan adil terhadap siswa yang beragam budayanya (Linda Starr, 2004: 4).

3. Gaya pengajaran guru (teaching style).

Selain lingkungan fisik dan sosial, siswa juga memerlukan gaya pengajaran guru yang menggembirakan. Menurut Garcia (1982: 146), gaya pengajaran guru merupakan gaya kepemimpinan atau teknik pengawalan yang digunakan guru dalam proses pembelajaran (the kind of leadership or governance techniques a teacher uses). Dalam proses pembelajaran, gaya kepemimpinan guru sangat berpengaruh bagi ada-tidaknya peluang siswa untuk berbagi pendapat dan membuat keputusan. Gaya kepemimpinan guru berkisar pada otoriter, demokratis, dan bebas (laizzes faire). Gaya kepemimpinan otoriter tidak memberikan peluang kepada siswa untuk saling berbagi pendapat. Apa yang diajarkan guru kepada siswa ditentukan sendiri oleh sang guru. Sebaliknya, gaya kepemimpinan guru yang demokratis memberikan peluang kepada siswa untuk menentukan materi yang perlu dipelajari siswa. Selanjutnya, guru yang menggunakan gaya kepemimpinan bebas (laizzes faire) menyerahkan sepenuhnya kepada siswa untuk menentukan materi pembelajaran di kelas. Untuk kelas yang beragam latar belakang budaya siswanya, agaknya, lebih cocok dengan gaya kepemimpinan guru yang demokratis (Donna Styles, 2004: 3).

Melalui pendekatan demokratis ini, para guru dapat menggunakan beragam strategi pembelajaran, seperti dialog, simulasi, bermain peran, observasi, dan penanganan kasus (Abdullah Aly, 2003: 70-1). Melalui dialog para guru, misalnya, mendiskusikan sumbangan aneka budaya dan orang dari suku lain dalam hidup bersama sebagai bangsa. Selain itu, melalui dialog para guru juga dapat mendiskusikan bahwa semua orang dari budaya apa pun ternyata juga menggunakan hasil kerja orang lain dari budaya lain. Sementara itu, melalui 
simulasi dan bermain peran, para siswa difasilitasi untuk memerankan diri sebagai orangorang yang memiliki agama, budaya, dan etnik tertentu dalam pergaulan sehari-hari. Dalam momen-momen tertentu, diadakan proyek dan kepanitiaan bersama, dengan melibatkan aneka macam siswa dari berbagai agama, etnik, budaya, dan bahasa yang beragam. Sedangkan melalui observasi dan penanganan kasus, siswa dan guru difasilitasi untuk tinggal beberapa hari di masyarakat multikultural. Mereka diminta untuk mengamati proses sosial yang terjadi di antara individu dan kelompok yang ada, sekaligus untuk melakukan mediasi bila ada konflik di antara mereka.

Dengan strategi pembelajaran tersebut para siswa diasumsikan akan memiliki wawasan dan pemahaman yang mendalam tentang adanya keragaman dalam kehidupan sosial. Bahkan, mereka akan memiliki pengalaman nyata untuk melibatkan diri dalam mempraktikkan nilai-nilai dari pendidikan multikultural dalam kehidupan sehari-hari. Sikap dan perilaku yang toleran, simpatik, dan empatik pun pada gilirannya akan tumbuh pada diri masing-masing siswa. Dengan demikian, proses pembelajaran yang difasilitasi guru tidak sekadar berorientasi pada ranah kognitif, melainkan pada ranah afektif dan psikomotorik sekaligus. Selanjutnya, pendekatan demokratis dalam proses pembelajaran dengan beragam strategi pembelajaran tersebut menempatkan guru dan siswa memiliki status yang setara (equal status), karena masing-masing dari mereka merupakan anggota komunitas kelas yang setara juga. Setiap anggota memiliki hak dan kewajiban yang absolut. Perilaku guru dan siswa harus diarahkan oleh kepentingan individu dan kelompok secara seimbang. Aturanaturan dalam kelas harus dibagi untuk melindungi hak-hak guru dan siswa.

Adapun hak-hak guru dalam proses pembelajaran meliputi:

1. Guru berhak menilai para siswa sebagai manusia dan hak mereka sebagai manusia;

2. Guru berhak mengetahui kapan menerapkan gaya pengajaran yang berbeda seperti otoriter, demokratis, dan bebas untuk meningkatkan hak-hak siswa;

3. Guru berhak mengetahui kapan dan bagaimana menerapkan ketidakpatuhan sipil;

4. Guru berhak memahami kompleksitas aturan bagi mayoritas dan melindungi hak-hak minoritas.

Di pihak lain, para siswa memiliki hak-hak sebagai berikut:

1. Siswa berhak mengetahui hak sipil dan kewajibannya;

2. Siswa berhak mengetahui bagaimana menggunakan hak dan kewajibannya (Garcia, 1982: $160)$.

\section{PENUTUP}


Pendidikan multikultural sebagai wacana baru di Indonesia dapat diimplementasikan tidak hanya melalui pendidikan formal namun juga dapat dimplementasikan dalam kehidupan masyarakat maupun dalam keluarga. Dalam pendidikan formal pendidikan multikultural ini dapat diintegrasikan dalam sistem pendidikan melalui kurikulum mulai Pendidikan Usia Dini, SD, SLTP, SMU maupun Perguruan Tinggi. Sebagai wacana baru, Pendidikan Multikultural ini tidak harus dirancang khusus sebagai muatan substansi tersendiri, namun dapat diintegrasikan dalam kurikulum yang sudah ada tentu saja melalui bahan ajar atau model pembelajaran yang paling memungkinkan diterapkannya pendidikan multikultural ini. Di Perguruan Tinggi misalnya, dari segi substansi, pendidikan multikultural ini dapat dinitegrasikan dalam kurikulum yang berperspektif multikultural, misalnya melalui mata kuliah umum seperti Kewarganegaraan, ISBD, Agama dan Bahasa. Demikian juga pada tingkat sekolah Usia Dini dapat diintegrasikan dalam kurikulum pendidikan misalnya dalam Out Bond Program, dan pada tingkat SD, SLTP maupun Sekolah menengah pendidikan multikultural ini dapat diintegrasikan dalam bahan ajar seperti PPKn, Agama, Sosiologi dan Antropologi, dan dapat melalui model pembelajaran yang lain seperti melalui kelompok diskusi, kegiatan ekstrakurikuler dan sebagainya.

Dalam Pendidikan non formal wacana ini dapat disosialisasikan melalui pelatihanpelatihan dengan model pembelajaran yang responsive multikultural dengan mengedepankan penghormatan terhadap perbedaan baik ras suku, maupun agama antar anggota masyarakat.

Tak kalah penting wacana pendidikan multikultural ini dapat diimplementasikan dalam lingkup keluarga. Di mana keluarga sebagai institusi sosial terkecil dalam masyarakat, merupakan media pembelajaran yang paling efektif dalam proses internalisasi dan transformasi nilai, serta sosialisasi terhadap anggota keluarga. Peran orangtua dalam menanamkan nilai-nilai yang lebih responsive multikultural dengan mengedepankan penghormatan dan pengakuan terhadap perbedaan yang ada di sekitar lingkungannya (agama, ras, golongan) terhadap anak atau anggota keluarga yang lain merupakan cara yang paling efektif dan elegan untuk mendukung terciptanya sistem sosial yang lebih berkeadilan.

\section{DAFTAR PUSTAKA}

Banks, J (1993), Multicultural Eeducation: Historical Development,Dimension, and Practice. Review of Research in Education.

—, (1994), An Introduction to Multicultural Education, Needham Heights, MA

Kuper, Adam \& Jessica Kuper (2000), Ensiklopedi Ilmu-Ilmu Sosial. Jakarta: PT Raja Grafindo Persada. 
Sugiri, Sugiri \& Sulfemi, Wahyu Bagja. (2011). Pendidikan Multi Kultur di Sekolah Berbasis Keagamaan. Edutecno. 3 (2), 11-20.

Sulfemi, Wahyu Bagja. (2007). Ilmu Sosial Dasar. Bogor : STKIP Muhammadiyah Bogor.

Sulfemi, Wahyu Bagja. (2009). Modul Pembelajaran Pendidikan Pancasila dan Kewarganegaraar. Bogor : STKIP Muhammadiyah Bogor.

Sulfemi, Wahyu Bagja. (2015). Kemampuan Pedagogik Guru. Prosiding Seminar Nasional. STKIP Muhammadiyah Bogor 1. (1). 71-83.

Sulfemi, Wahyu Bagja. (2016). Modul Pembelajaran Ilmu Sosial dan Budaya Dasar. Bogor : STKIP Muhammadiyah Bogor.

Sulfemi, Wahyu Bagja. (2016). Perundang-Undangan Pendidikan. Bogor : Program Studi Administrasi Pendidikan STKIP Muhammadiyah Bogor.

Sulfemi, Wahyu Bagja. (2018). Manajemen Kurikulum di Sekolah. Bogor : Visi Nusantara Maju.

Sulfemi, Wahyu Bagja. (2018). Modul Manajemen Pendidikan Non Formal. Bogor: STKIP Muhammadiyah Bogor

Sulfemi, Wahyu Bagja. (2018). Hubungan Motivasi Belajar Dengan Hasil Belajar IPS Di SMP Kabupaten Bogor. Edutecno 18 (2), 1-8.

Sulfemi, Wahyu Bagja. (2019). Manajemen Pendidikan Berbasis Multi Budaya. Bogor : STKIP Muhammadiyah Bogor .

Undang-Undang Republik Indonesia Nomor 20 Tahun 2003 Tentang Pendidikan Nasional.

Zubaidi (2005), Pendidikan Berbasis Masyarakat. Jakarta: Pustaka Pelajar. 